International Journal of Current Advanced Research

ISSN: O: 2319-6475, ISSN: P: 2319 - 6505, Impact Factor: SJIF: 5.995

Available Online at www.journalijcar.org

Volume 6; Issue 4; April 2017; Page No. 3194-3197

DOI: http://dx.doi.org/10.24327/ijcar.2017.3197.0222

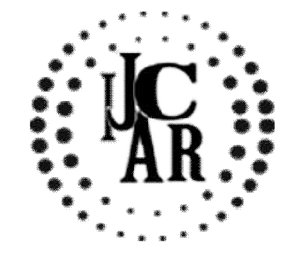

Research Article

\title{
FIFTH VARNA OF THE INDIAN SOCIETY
}

\author{
Abhilasha and Rakesh Paraste
}

Department of EFL IGNTU, Amarkantak

\begin{tabular}{|c|c|}
\hline 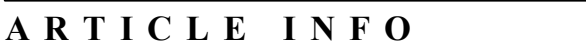 & A B S T R A C T \\
\hline $\begin{array}{l}\text { Article History: } \\
\text { Received } 18^{\text {th }} \text { January, } 2017 \\
\text { Received in revised form } 19^{\text {th }} \text { February, } 2017 \\
\text { Accepted } 15^{\text {th }} \text { March, } 2017 \\
\text { Published online } 28^{\text {th }} \text { April, } 2017\end{array}$ & $\begin{array}{l}\text { Indian Society has long been assigned four varnas which are now mingling and merging } \\
\text { slowly but steadily. Value and Times are relative. But what is stunning is that nobody } \\
\text { talked about this fifth one, though, this varna is ubiquitous. It is part and parcel of all the } \\
\text { four, yet it is nowhere. Religious controversies are not unknown to India or for that matter } \\
\text { entire world. But when it comes to the fifth varna all the religions are unanimously united } \\
\text { on eliminating the recognition or erasing whatever identity this fifth one has got. } \\
\text { I am talking about 'woman' varna. She is Brahmin, she is Kshatriya, she is Vaishya and she } \\
\text { is Sudra. But nowhere is she a human being. Man is a born human but a woman is an } \\
\text { afterthought. Man is entitled to earn Dharma, Arth, Kaama and Moksha. She is there only } \\
\text { to facilitate man in all his efforts. She is not a free entity. She cannot have a free will of her } \\
\text { own. If she dares to have one she should be ready to pay the price. In theory she has } \\
\text { received accolades of praise. But in practice she has got all that even an animal will rebel } \\
\text { against. }\end{array}$ \\
\hline
\end{tabular}

Copyright $₫ 2017$ Abhilasha and Rakesh Paraste. This is an open access article distributed under the Creative Commons Attribution License, which permits unrestricted use, distribution, and reproduction in any medium, provided the original work is properly cited.

\section{INTRODUCTION}

"Giving freedom to women was thought of as the precursor of doom", but this certainly began to change in the 19th century. During the colonial period the British tried to solve and eradicate some of the social problems of India and framed rules for infanticide, child marriage, the prohibition of widow remarriage and overall deplorable status of Indian women. Laws like Bengal Regulation Act XXI termed female infanticide as a murder and Consummation of marriage age was increased to ten, then twelve and then to fourteen. Abolition of Sati Act was passed in 1829 and Hindu Widow's Remarriage Act was passed in 1856. All these attempts made by laws tried to ameliorate the inhuman plight of women but society was not able or rather ready to overcome its ossified social practices which had created a rigid binary opposition between man/woman. Women though being part of the society were bereft of basic human rights and were forced to live under subjugation of men as prescribed by religion/s and religious scriptures, of course penned by Man or Men.

Apart from the British their dismal condition was first realized by the $19^{\text {th }}$ century intelligentsia like Raja Ram Mohan Roy, M.G. Ranade, Ishwar Chandra Vidyasagar, Joytiba Phule etc. These social reformers armed with the western education and a new outlook towards life and social obligations were ready to look before and after and found many social practices as simply evil, inhuman and outrageous.

*Corresponding author: Abhilasha

Department of EFL IGNTU, Amarkantak
They worked for the betterment of the condition of Indian women by banning of sati, allowing and provoking the social conscience for widow remarriage but most of all they said that women must be educated. Though most of these movements were headed by males we have some women's voices also that were cleverly silenced by the literary, social or historical canons. This paper tries to explore one such voice i.e. the voice of Pandita Ramabai.

Pandita Ramabai was, in the words of a well-known scholar and humanist A.B. Shah, who published her letters and correspondence under the auspices of the Maharashtra State Board for Literacy and Culture in 1977 "the greatest woman produced by modern India and one of the greatest Indians in all history...the one to lay the foundations for a movement for women's liberation in India. (Autobiography, Pandita Ramabai, Woman of the Millenium, Genesis Books Publishing, TrimurtiChowk, Nasik, 31.)" But strangely enough when it comes to Women Liberation Movement in India, contemporary consciousness hardly gives her credit for the initiation. Her own time also tried to silence her voice, no doubt.

She was called 'Rama' by her parents meaning 'bright'. And she proved her name. She is the first Indian woman to be awarded 'Kaiser-I-Hind' medal for her community service in 1919. She is the first woman Bible translator and the first to start a special school for visually handicapped in India. She established Arya Mahila Samaj in 1882 to protect the interests of women and to discourage child-marriage. Born to an unorthodox 'vidwan' Chitpavan Brahmin father Anant Shastri 
Dongre, and a learned mother Laksmibai, an unusual matter for that time, Ramabai inherited from them an indomitable will and fighting spirit. She grew up as a wanderer and was free from the binds of a traditional society. Perhaps this was the reason that she was able to achieve later in life more than the other women in her time. She was also one of the chosen few in the $19^{\text {th }}$ century who supported themselves from their writing. Her first venture into the field of writing Stree Dharma (Morals for Women) 1882, was sufficient enough to pay for her passage to England, an unusual thing for a woman writer. The first edition of ten thousand copies of High Caste Hindu Woman 1888, paid for her journey to United States. All these journeys of hers were meant to raise her voice for Indian woman, so that entire world may listen and help her in her fight to dispel some of the inhuman social practices like castigation of a widow by Indian society. At the same time it also revealed her iron will and her refusal to sacrifice her freedom of thought and speech, but all these extraordinariness of her character landed her deeper into the social controversies of her time. Her acts and words may appear radical to so many even in the $21^{\text {st }}$ century. When Taslima Nasreen from Bangla Desh wrote about religion and how adversely it can affect women her writing was banned and she was banished from her country. Tehmina Durrani from Pakistan had to face the err of society and her family for opening up her mouth against the patriarchy and its mutilating effects on a woman's survival as a human being. She was disowned by her family and friend alike.

She was born in an ashram on April $3^{\text {rd }} 1858$ in Canra district of British India which is now in Karnataka. Her father, an intellectual Brahmin with deep knowledge of the Vedas, was very much concerned with the conditions of women. He raised some pertinent questions as to why women and sudras are deprived of knowing the Vedas, why they are denied the right of education compelling them to lead a subhuman life.

Perhaps this is the reason the voice of a woman like Ramabai became a clarion call for the Indian history of her time. When even freedom fighters like Tilak, Gokhle and Ranaday were not that much vocal about conditions of Indian women and what can be done to redress their plight, Ramabai came to the fore to tell the society that before she is a woman, she too is a 'human' being. She needs all that is needed by a man to grow and be worthwhile in and for society, that she too needs to be educated, and her home should not be her cage, and that she too needs her own space to breathe. She had read widely all the religious scriptures of Hinduism like the Vedas, Upanishads, Shrutis and Vedants and the more she read the more dissatisfied she became with the current practices of high class Brahminical ways of governing the society. One is born a Sudra, or a woman for that matter, because of certain bad deeds (theory of Karma) in the previous birth and atonement is possible if a sudra serves the higher class like Brahmin and a woman serves her husband as her immediate God.

It is also very strange that the class which chose her for her learning as a symbol of pristine glory of a Hindu woman like Gargi and Maitrye was the most disappointed one by her rebellious act; for speaking out her own mind, for questioning the fundamental propositions of Brahmanic Hinduism instead of representing their vested interest. The fact was that hers was not rote learning, rather she analyzed everything, reasoned everything and questioned every dictates before accepting it as truth. That is what she had learned from her parents who were not ready to bend before false gods, the controller and manager of society, the Brahmans. Her own father was castigated and almost ostracized for teaching her young wife Sanskrit and Vedas by his own family members as well as the social gurus. And this is the reason her parents chose to create their own Eden where nobody was to exile them for breaking the societal norms like imparting knowledge to womenfolk. It was here that Ramabai was born, the youngest of her siblings hence the most adored one by her father. When her family was under the devastating grip of famine of 1877 like millions, her father Anant Shastri Dongre chose to die rather than beg and while ready to face the inevitable he called his daughter and, "his last loving command to me was to live an honourable life, if I lived at all, and serve god all my life...'As you are the last of my children, you are dearest to me...I have given you into god's keeping, he will guard you(C.f. Pandita Ramabai a Life \& a Time by Uma Chakravarti, 6)". Ramabai soon lost both her parents and her sister as well, "I cannot describe all the sufferings of that terrible time. My father, mother, and sister, all died of starvation within a few months of each other...my brother and I survived and wandered... from the south to the north as far as Kashmir and then to the east Culcutta in 1878 (A Testimony of Our Inexhaustible Treasure, 16)" .

The visit to Culcutta was momentous in her life as she was welcomed by the reformers and the elites with much applause. She was the living perception of ancient woman hood and recovery of the lost figures of Gargi and Maitreyi. Her euphoric reception in Culcutta shows the intellectual framework of the place also where she was asked to lecture on women, their emancipation, education and the 'Rise and Fall of the Aryan Race'. It was here that she was suggested to read Vedas by the leading Brahmo reformer Keshub Chandra Sen which later on, was to plant the seeds of rebellion in the heart of Ramabai. To lecture on the duties of women as per the Shastras, she first read the Shastras herself and started questioning the fundamental propositions of Brahmanic Hinduism. She came to know that there were contradictory statements concerning women in almost all the Hindu religious scriptures and this belief was later on cemented when she found the same in Christianity as well. Ramabai sought to understand the self, the woman's self, in relation to society historically and politically, as well as the interior self, often through personal experiences, like motherhood and marriage. Exploration into the interior self characterizes her works like The High Caste Hindu Women etc.

Building on the $19^{\text {th }}$ century ideology that promoted Indian cultural and racial self-discovery by the social reformers of the time Ramabai stressed the necessity of women's education and also freedom from the age-old shackles of Brahminism. She, after studying the Hindu scriptures like Vedas and Upanishads, realized that religion works as social ethical directives and it has put women into a quagmire of ageless infancy where she is expected to shun her individuality forever. Ramabai questioned this perception of ancient Indian Womanhood and wrote: "While reading the Dharmashastras I came to know many things which I never knew before. There were contradictory statements about almost everything...but there were two things on which all those books the Dharmashastras, the sacred epics, the Puranas and 
modern poets, the popular preachers of the present day and orthodox high caste men were agreed, that women of the high and low caste, as a class were bad, worse than demons, as unholy as untruth and that they could not get moksha (like) men. The only hope of their...liberation... was the worship of their husbands. The husband is said to be a woman's god; there is no other god for her. This god may be the worst sinner and a great criminal; still he is her god and she must worship him...The extra-ordinary religious acts which help a woman to get...moksha are utter abandonment of her will to that of her husband" (A Testimony of Our Inexhaustible Treasure, 18-20).

She further wrote "My eyes were gradually opened: I was awakening up to my own hopeless condition as a woman, and it was becoming clearer and clearer to me that I had no place anywhere as far as religious consolation was concerned. I became quite dissatisfied with myself. I wanted something more than Shastras could give me..." (21). She wanted, as a woman, the right to exist as a human, with her own individuality and it was here exactly that she was disappointed by both society and social reformers. When she wrote her first book Stri Dharma Niti she was idolized by the male reformers of the $19^{\text {th }}$ century as the book was conforming and supporting their ideologies, but when she started critiquing the religious and social or patriarchal dictates it was taken to be her audacity for which there was no excuse by the society.

Women though part of the society were bereft of basic human rights and were forced to live a sub-human life. Their dismal condition was first realized by the $19^{\text {th }}$ century intelligentsia like Raja Ram Mohan Roy, M.G. Ranade, Ishwar Chader Vidyasagar, Joytiba Phule etc. Though these reformers worked for the betterment of women in the society by banning sati, child marriage, allowing widow remarriage and education for women, these reformations were very much keeping in mind the religious and social prescriptions laid down by the ancient India. But when staunch women reformers such as Tarabai Shinde who wrote Stree Purush Tulna and Begaum Rokeya Sakhawat Hossain who wrote Sultana's Dream tried to awaken the society from women's point-of-view, they had to face severe criticism.

The modern day thoughts and planning to improve the conditions of women though are similar in spirit to the $19^{\text {th }}$ century the means are different as the odds faced by women in modern society is different. Women in $21^{\text {st }}$ century are subjected to domestic violence, dowry deaths, growing incidences of rapes, molestations, acid attack etc. Movements for the betterment of the condition of women are taken up by society and government as a whole rather than by any particular person. But still patriarchy and male chauvinism exists in the society which makes their condition no better than the $19^{\text {th }}$ century and the question about their status can be said to be derived from the $19^{\text {th }}$ century. Whether it is film industry, sports or private sectors women are paid less for the same amount of work. Hence one can realize the truth that when it is so very difficult to be a woman and exist at her own cost even in the $21^{\text {st }}$ century what would be her plight in the $19^{\text {th }}$ century. Being a widely travelled person in the very beginning of her life she had seen the heart-rending conditions of women, especially the young high-caste widows. And after her own widowhood at the tender age of
23, she made it her mission to show them a new way of life through education. She had had her own experience of

"the sense of social isolation (which) was further compounded by the absence of religious moorings. Her peculiar location as a woman without any close kin in a world of male reformers 'intellectually' engaged in transforming Brahmanical Hinduism without addressing central questions, all well established in professions and surrounded...by docile and loving women, needs to be borne in mind. Ramabai's search for personal fulfillment as well as her struggle to understand, and conceptualize women's oppression from her own position as a woman were vastly different from the motivations and worldview of the men around" (C.f. Pandita Ramabai a Life \& a Time by Uma Chakravarti, 10).

Ramabai's marriage with a sudra was without precedence but her widowhood and refusal to stay within the prescribed role of the society, that is withdrawal from active life made her a potential dangerous figure in the public gaze. "Except in the sheltered atmosphere of like-minded reformers Ramabai's public appearances, speaking on behalf of women, were too threatening and she was often shout down by aggressive men"( C.f. Pandita Ramabai a Life \& a Time, 11). Documenting one such lecture, Tagore wrote from Poona that 'the present day Bergis (Maharastrians) turned rowdy as soon as she got up to speak and that she had to sit down without finishing her speech' (Rabindra Racanabali, Vol. 13, 101f). Her public speech and suggestion to women were horrible for the orthodox men and women and her Arya Mahila Sabha was considered to be an institution set up to do away with the dominion of men. Despite her public appearance and location she found herself to be alone in search and fulfillment of her dream wish that is to set up a widow's home. But this was not shared by even the reformers of the time and very soon she became disenchanted and disillusioned by her own 'countrymen'. Now she decided to build her own skill of writing and tried to seek help from outside. In 1883 she left for England and to meet the expenses of her travel she wrote and published Stri Dharma Niti and dedicated it to the memory of her late husband. Though this book was in many ways conforming to the reformist agenda of the time but even this early book shows the independency of her thought. She clearly writes that a woman is more than a wife and daughter and as such she should cultivate her individuality with performing all the roles of a wife and mother. Even in England she showed her independence by taking the job of the teacher of Marathi and was warmly appreciated for that. It was here that she came into direct contact of the missionaries who saw in her a bright prospect for spreading Christianity in this country. She was also very much influenced by the missionary's works and her own hopeless condition as a Hindu widow, in her own religion, amongst her own people. She was drawn to the service aspect of Christianity where love and compassion for the fallen and sick was in contrast to the punishable and despicable aspect of Hinduism

"I had never heard or seen anything of the kind done for this class (fallen women) of women by the Hindus in my country... The Hindu shastras do not deal kindly with these women. The law of the Hindu commands that the king shall cause fallen women to be eaten by dogs in the outskirt of the town. They are considered the greatest sinners and not worthy of compassion" (Testimony, 26). 
This was in stark contrast with the compassionate views of the missionaries and their services for the betterment of such women. What attracted her more to her reasoning mind is that Christianity drew people into action and unlike Hindus not only philosophical about improving the next world. Christ then became to her a force that can help to save downtrodden women of India. After this realization she took the decision to break away from her ancestral religion and she was baptized on $29^{\text {th }}$ September 1883 along with her daughter Manorma then three years old. But this rational decision of hers caused an outcry in India damning her for what she has done. The editor of Indu Prakash wrote:

"Pandita Ramabai was in the first instance a Hindu, then she became a Brahmo, now she has become a Christian. This shows and proves she is of unstable mind. We should not be surprised if she becomes a Muslim soon. She has only to meet a Muslim Kazi who will convince her that his religion will give her peace and salvation" (Indu Prakash, 19 November 1883).

No reformist came on the fore even for little consolation except Jyotiba Phule. Only he defended Ramabai publicly and castigated the editors and their newspapers for their negative remarks on Ramabai's conversion. "He argued that Ramabai, as a truly educated woman, has seen for herself the bias of the Shastras towards the low castes and women and therefore could not but break with Brahmanic Hinduism... He suggested that the hysterical reaction of the male writers was because they were unwilling to accept a situation where women had taken to writing and expressing their dissent in print" (Satsar, 345-62). But Phule's voice was an exception to the general lashing out of Ramabai and calling her impure and fallen. Now they could not have used her as an example of educated Hindu woman endorsing Hindu culture. "Even Vivekanand and Ramakrishna denounced her. For Ramakrishna, Ramabai was too ambitious-she represented a kind of egotism and idealism which was not 'good' as it was a mere pursuit of name and fame" (Gospel of Shree Ramakrishna, 377). Vivekenand, on the other hand mourned the loss in her conversion of his cause of presenting the glory of ancient Hinduism before the West. "Will there be no women in the land of Maitreyi, Lilavati, Savitri and Ubhayabharti, who will venture to do this? (Selection from Swami Vivekenanda, 356)". When these mahapurushas(Great persons) could not condone her conscious break from their religion, common people's views can be imagined and no surprise that she was called batli (fallen, impure) by them.
Totally disappointed by her own time and its religion, failed by her society and its people she chose not to stop but moved ahead. She left her country, only to return back and serve its unfortunate daughters. She broke away from her religion only in search of a faith where humanity was of utmost value without the dissection of human as she and he. People from America listened her plea about the Indian widows, helped her and then help poured from various parts of the world to realize her long cherished dream, a dream which never allowed her to be in peace or take rest or compromise with all the threats and suffering inflicted by her Time and its practices. When in 1896, a terrible famine broke in Central India She and her helpers rescued several hundred women and they were provided shelter in the Mukti Sadan at Kedgaon in Pune. In 1900 when another famine broke in Gujrat and Kathiawar, again she came to the fore and now there were 1900 inmates in her Sadan. She ran her Sadan not only by the donations but started an industrial school with gardens, fields, oil press, dairy, laundry, ovens along with sewing, weaving and embroidery. These practices made the inmates of the Mukti Sadan organized and gave them a sense of independence and worth. Thus Pandita Ramabai carved out a niche for herself and walked on a path where no Hindu woman had dared to travel, defying her society, her religion and most of all the patriarchy.

\section{References}

1. C.f. Women Writing in India, 243. Vol.1, ed. by Susie Tharu and K.Lalita, Oxford University Press, 1991.

2. Chakravarti, Uma. Pandita Ramabai a Life \& a Time, Critical Quest, New Delhi.

3. Pandita Ramabai, A Testimony of Our Inexhaustible Treasure, 18-20, Kedgaon (Poona), Ramabai Mukti Mission, 1907, reprint 1992.

4. Rabindra Racanabali, Vol. 13, Centenary edition, Culcutta, West Bengal Government Publication, 1961.

5. Indu Prakash, 19 November 1883.

6. Satsar, September 1885, reproduced in Y.D. Phadke, Collected Works of Jyotiba Phule, Bombay, Maharastra Rajya Sahitya ani Sanskriti Mandal, 1991.

7. Gospel of Shree Ramakrishna, c.f. Padmini Sengupta Pandita Ramabai Saraswati, Bombay, Asia Publishing House 1970.

8. Selection from Swami Vivekenanda, Almora, Advaita Ashrama, 1946.

9. Autobiography, Pandita Ramabai, Woman of the Millennium, Genesis Books Publishing, Trimurti Chowk, Nasik.

\section{How to cite this article:}

Abhilasha and Rakesh Paraste (2017) ' Fifth Varna Of The Indian Society', International Journal of Current Advanced

Research, 06(04), pp. 3194-3197.

DOI: http://dx.doi.org/10.24327/ijcar.2017.3197.0222 